\title{
HMS Falmouth: 3D Visualization of a First World War Shipwreck
}

\author{
Antony Firth, Jon Bedford, and David Andrews
}

\begin{abstract}
This chapter outlines an opportunistic yet innovative approach to developing a 3D visualization of HMS Falmouth, a Town Class light cruiser sunk during the First World War on the Yorkshire coast, England. The results of a multibeam echosounder survey of the seabed were combined with photogrammetry and laser scanning of the original builder's model of HMS Falmouth, which is in store in the collections of the Imperial War Museums (IWM). The visualization, made available via Sketchfab, helped to generate considerable public and media interest in an important heritage asset. This chapter also comments on the role of visualizations in engaging people for whom underwater archaeology is otherwise inaccessible, and considers the potential for visualizations to integrate research and prompt further investigation.
\end{abstract}

\section{Keywords}

Naval history $\cdot$ Historic shipwreck $\cdot$ Ship model $\cdot 3 \mathrm{D}$ modelling

\subsection{Introduction}

There are so many shipwrecks around the coast of the UK especially from the conflicts of the twentieth century that their heritage interest is overlooked both in archaeological terms and more widely amongst the public. The wealth of the

A shorter version of this chapter previously appeared in Issue 7 (Autumn 2017) of Historic England Research.

\footnotetext{
A. Firth $(\bowtie)$

Fjordr Limited, Tisbury, Wiltshire, UK

e-mail: ajfirth@fjordr.com

J. Bedford · D. Andrews

Historic England, York, UK

e-mail: jon.bedford@historicengland.org.uk; david.andrews@

historicengland.org.uk
}

UK's underwater cultural heritage receives a fraction of the attention and care directed to otherwise comparable heritage on land, perhaps only because it is out of sight and out of mind. Yet when shipwrecks are brought to light, public fascination is clearly apparent (Kenderdine 1998, 23). In such circumstances, the potential role and value of 3D visualization in engaging people's interest is self-evident.

This chapter outlines an opportunistic yet innovative approach to developing a 3D visualization of HMS Falmouth, sunk as a result of U-boat attacks in August 1916 and lying wrecked just off the coast of Yorkshire. The scope of the visualization was set by circumstances and the component methodologies were not new (Firth 2011; Menna et al. 2011), but the juxtaposition within an online, accessible visualization of the wreck and the ship together is relatively novel. The visualization successfully achieved its principal aim of bringing the story of HMS Falmouth to many more people than might have been the case otherwise. The visualization, however, also prompts a series of further considerations about visualizations as a focus for engagement, research and heritage management.

\subsection{Background}

HMS Falmouth is an accessible and well-known wreck site. The general depth of the seabed is $16 \mathrm{~m}$ below Chart Datum and the wreck is located about $8 \mathrm{~km}$ offshore, about $12 \mathrm{~km}$ from the nearest harbour at Bridlington. After it was sunk by U-boats in August 1916, salvage work by the Royal Navy commenced almost immediately (ADM 116/1508). Despite the relatively shallow depth the ship could not be recovered intact, but most of the main armament and some other fittings were removed. Although details are unavailable it seems that the wreck was cleared as a navigational hazard and targeted by commercial salvors in the interwar period. HMS Falmouth has been dived by recreational divers since the 1970s and further piecemeal salvage has 


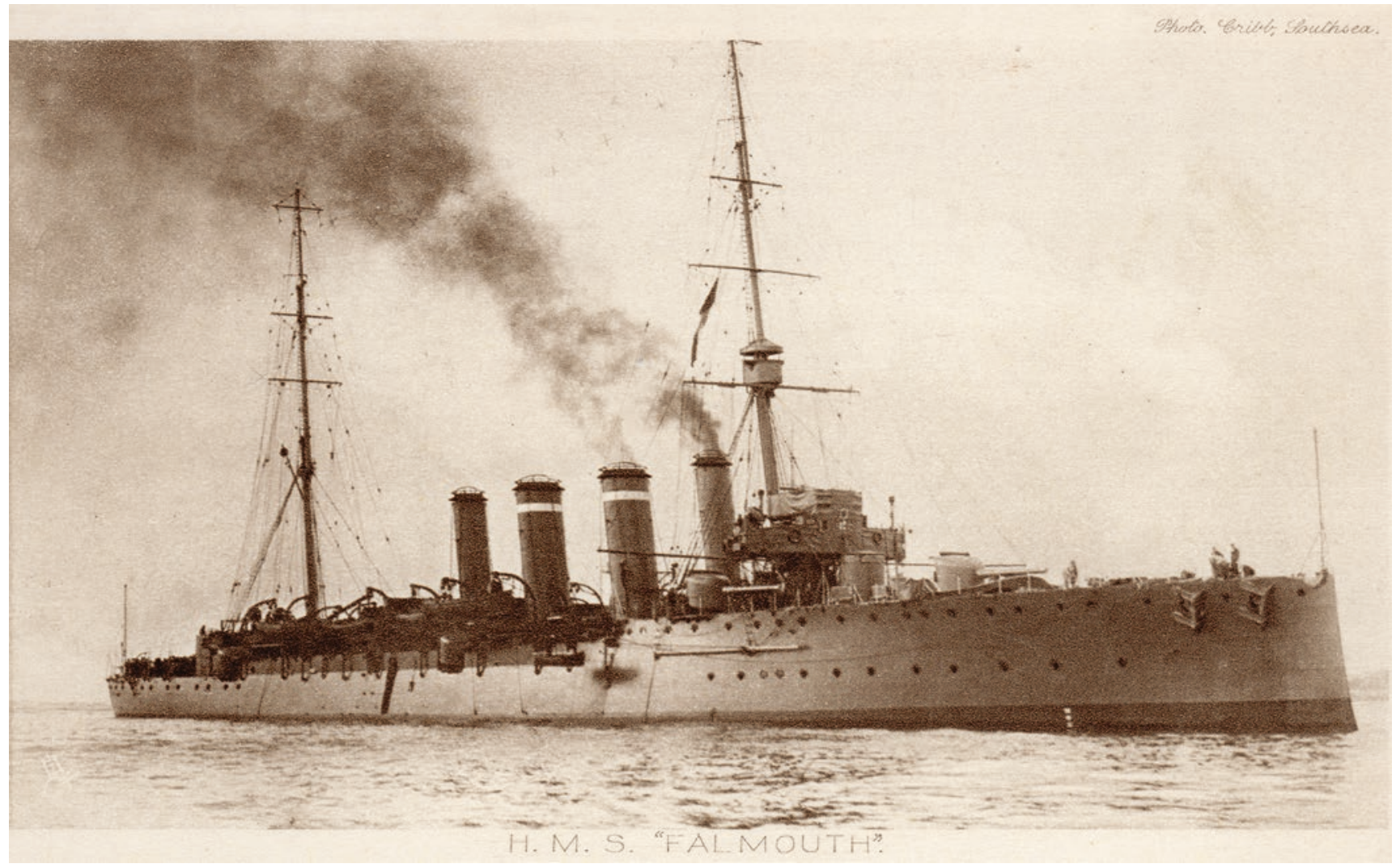

Fig. 12.1 Contemporary postcard of the Town Class light cruiser HMS Falmouth

occurred-possibly on a large scale. Given this amount of disturbance, exacerbated by natural processes, HMS Falmouth has been described as a 'mangled wreck ... fascinating for rummagers' (Divernet n.d.).

The basic details of HMS Falmouth and its loss are well known (Lyon 1977; Newbolt 1928) but the overall significance of the ship and the wreck have been overlooked. Fjordr Limited, a heritage consultancy, proposed a project to Historic England-the national heritage agency for England-to examine the significance of HMS Falmouth and to raise awareness, especially amongst the wider public who visit or live at the coast but are not aware of their heritage just offshore. The project linked the question of significance directly to the potential to develop greater social and economic benefits from maritime heritage, especially in struggling coastal communities. The project was commissioned by Historic England and resulted in a series of outputs, including a formal Statement of Significance (Firth 2016a) and a fold-out leaflet (Firth 2016b) that was distributed through Tourist Information Centres and local museums.

Both the Statement of Significance and the fold-out leaflet addressed the build, use and loss of HMS Falmouth as a complete 'ship biography.' This included setting HMS
Falmouth in its context as a Town Class light cruiser, a class that embodied features of the Dreadnought revolution in a vessel with global reach. Members of this class were heavily used in the First World War, participating in many key engagements. HMS Falmouth was no exception. Stationed in the North Sea at Scapa Flow and then Rosyth on the Firth of Forth, Falmouth took part in numerous sweeps to intercept fishing vessels and merchant ships as well as in fleet actions, notably the First Battle of Heligoland Bight and the attempted interception of the German raid on Scarborough, Whitby and Hartlepool. At the Battle of Jutland, HMS Falmouth was the flagship of the Third Light Cruiser Squadron attached to the Battle Cruiser Fleet, engaging repeatedly with the German fleet (Fig. 12.1). Falmouth was again involved in a major operation by the Grand Fleet to intercept the German fleet on 19 August 1916 when the ship was torpedoed by a U-boat in the North Sea about $110 \mathrm{~km}$ east of Scarborough. Strenuous efforts were made to reach the safety of the Humber over the next $28 \mathrm{~h}$, despite torpedo hits from a further U-boat, but the ship succumbed just offshore (Firth 2016a).

The century between 1850 and 1950 saw significant change in steam-powered iron and steel cargo ships and warships. Few larger vessels from this revolutionary period, however, survive in preservation as museum ships 
and, outside the former Royal Dockyards, little survives of the UK's shipbuilding heritage on land. It is a paradox that the principal survivors of Britain's mid-nineteenth- to midtwentieth-century maritime heritage are those that were sunk and now lie on the seabed; almost all of the vessels that reached the ends of their careers still afloat were scrapped to leave no physical trace (Firth 2016c; Firth and Rowe 2016). The apparent absence of the material remains of this aspect of the UK's national story in this periodtimes that are otherwise well-represented by built heritage, industrial archaeology and all manner of preserved vehicles and aircraft - ought to be a concern not only for those who have a technical interest in ship construction or military history. The material heritage of all those communities engaged in shipbuilding, in seafaring and in maritime commerce and conflict more broadly has been erased except for those elements that are currently hidden by the waves. Furthermore, for most of the period since sinking this heritage has often been subject to damaging salvage and clearance activities, whilst its intrinsically unstable character suggests that it will suffer further degradation in coming decades.

This is true of all that HMS Falmouth represents. The civil shipbuilding yard of Beardmore's on the Clyde where Falmouth was built now lies under an industrial estate, a hospital and a hotel. Falmouth is the only known survivor of the important Town Class; all the others were scrapped-mostly in the 1920s and 1930s (Lyon 1977)-except for HMS Nottingham also sunk by U-boats in the same operation as Falmouth but whose wreck has yet to be found. Although there are others elsewhere-and the surviving HMS Caroline now receiving attention in preservation-Falmouth is also the only substantial wreck of a veteran of Jutland in England's territorial waters. Both in itself and as a representative of its class, this overlooked 'rummage' is a rare and significant part of our twentieth-century maritime heritage. Subsequent to the project, HMS Falmouth was designated under the Protection of Military Remains Act 1986; but this designation, administered by the Ministry of Defence, reflects the loss of service personnel and entails no proactive provision for future management of the wreck as a heritage site.

\subsection{Origins of the 3D Visualization of HMS Falmouth}

It is fortunate that 3D technologies for acquisition and visualization of underwater sites have become available just as the heritage value of nineteenth- and twentieth-century wrecks has begun to be recognized. Indeed, the ability to 'see' what survives on the seabed has probably contributed-with some key anniversaries-to recognising more recent wreck sites as heritage, even amongst archaeologists. Shipwrecks built from, or with major components made from, iron and steel tend to be extensive, complex and highly three-dimensional in the field, presenting difficulties to the conventional recording methods available to marine archaeologists up to the mid-1990s. The capability and increasingly mainstream availability of multibeam, photogrammetry and $3 \mathrm{D}$ visualization software have made the recording and interpretation of mid-nineteenth- to mid-twentieth-century shipwrecks possible in a way that could barely be contemplated just a few decades ago. Achieving a basic 2D survey would be the work of many hours underwater; the results of which are now far surpassed in minutes. The radical impact that this is having on our capacity to interpret underwater sites and to share them with a much wider public who need never approach the water, let alone go diving, will take time to fully appreciate as the technology sprints along. Although relevant to many types of site, for the archaeology of twentieth-century wrecks such as HMS Falmouth these are very exciting times.

Nonetheless, creating a 3D visualization of HMS Falmouth was not part of the original project. The possibility arose opportunistically and with only a short timeframe available before the results of the project were due to be launched. The first piece of luck was that the Maritime and Coastguard Agency (MCA) - the government agency responsible for navigational safety - was planning a high resolution multibeam survey off the Yorkshire coast as part of their Civil Hydrography Programme. Although not in the planned survey area, the MCA agreed to add a survey of HMS Falmouth to their contractor's programme for a modest contribution from Historic England. The survey was carried out by the MCA's survey contractor MMT aboard M/V SeaBeam using a Kongsberg EM2040D, which is a dual-head multibeam echosounder used for high resolution bathymetric surveying, and the survey was conducted in accordance with the MCA's standard specification for wreck investigation surveys (Fig. 12.2). The results were made available to the HMS Falmouth project in May 2016. The survey is excellent and captured many details of the wreck, showing that despite a great deal of degradation the wreck clearly retains a fair amount of overall coherence. Features such as the distinctive Y-shaped Yarrow boilers can be identified in the multibeam data and related to original drawings and to photographs taken by divers of the wreck on the seabed. Obtaining such a detailed survey was itself a major contribution to better understanding the survival and significance of the wreck.

The second piece of luck concerned the builder's model of HMS Falmouth (Fig. 12.3). As a result of collaboration with the National Museum of the Royal Navy over the Jutland 36 Hours exhibition (Firth 2016c), Fjordr became aware of a model of HMS Falmouth in the stored collection 


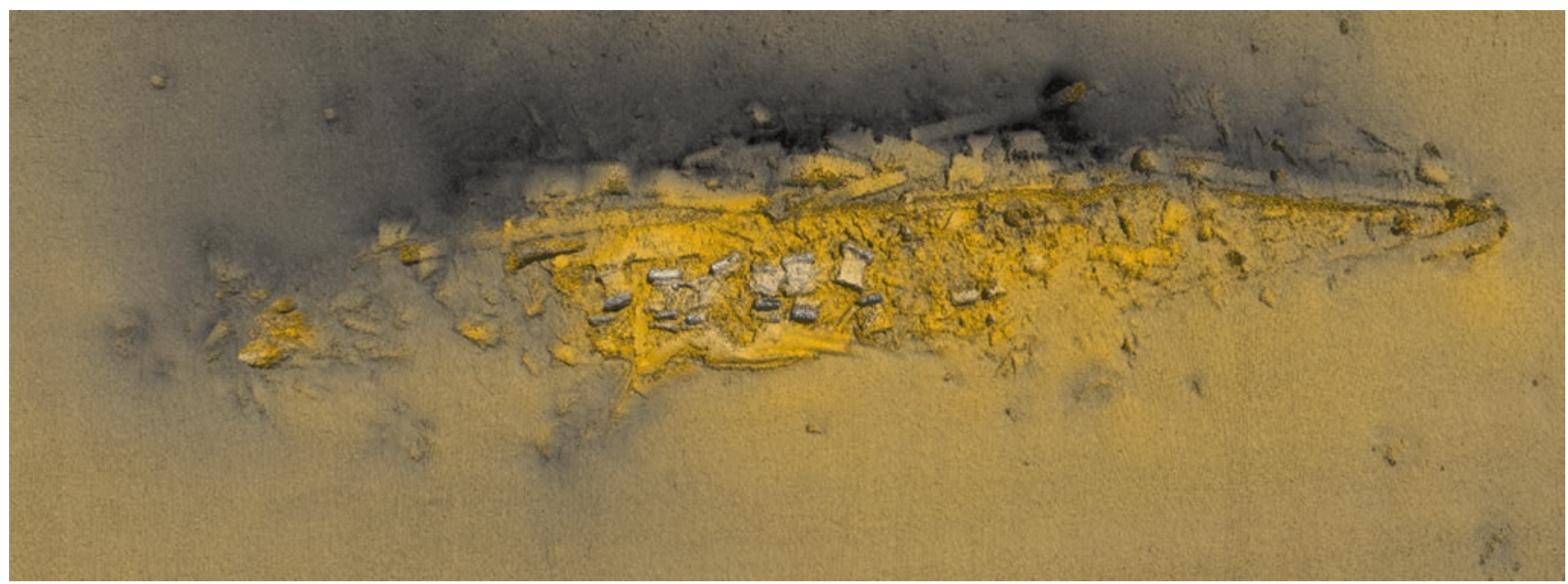

Fig. 12.2 Results of multibeam survey of HMS Falmouth by MMT for Civil Hydrography Programme. (Maritime and Coastguard Agency (C) Crown copyright)

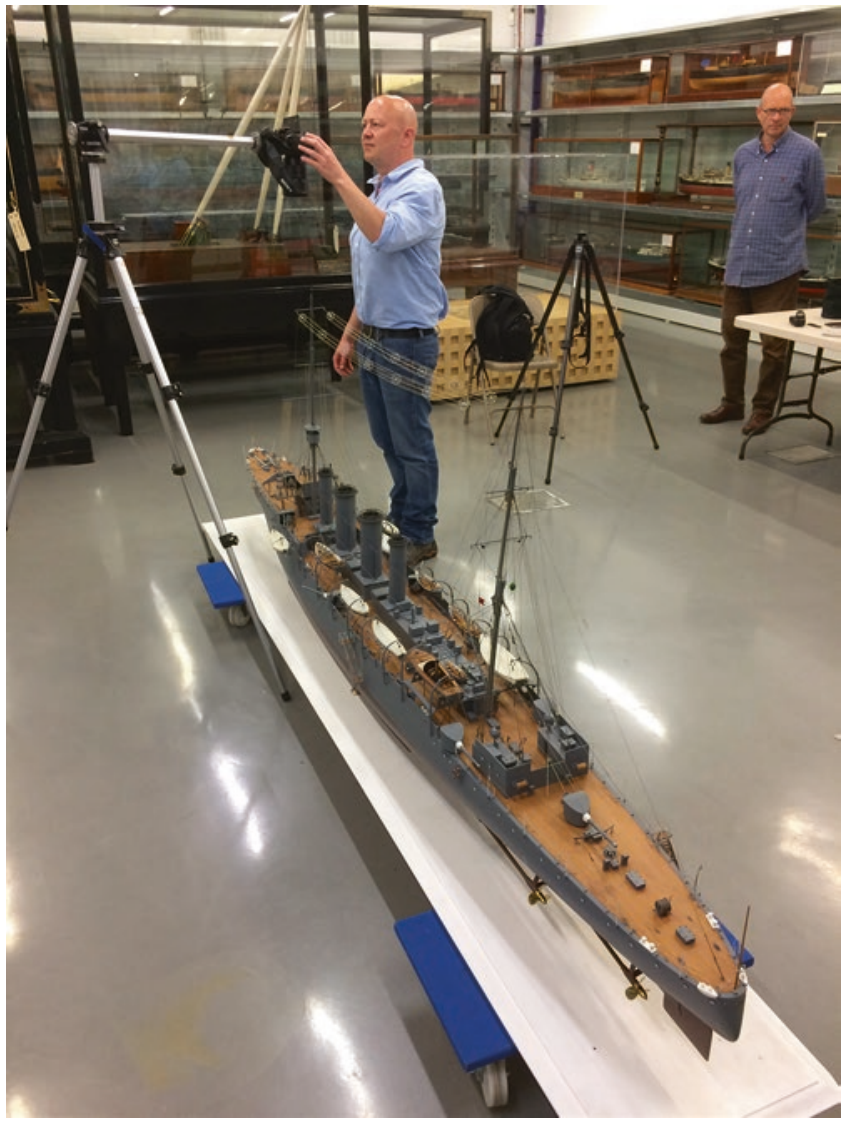

Fig. 12.3 Photogrammetric survey of the builder's model of HMS Falmouth, carried out by Historic England Geospatial Imaging team at the Chatham store of the Imperial War Museums. Antony Firth, Fjordr

of the Imperial War Museums. Few details and no photographs of the model were available from IWM. Model maker John Haynes, however, had been commissioned to restore the model in 1979. Haynes kindly supplied photographs of the model before and after restoration. The model was a large-scale builder's model which is presumed to have been made by Beardmore's in 1910-1911. The model formed part of the King's ship model collection, which became part of the Imperial War Museums' collection when it was established in 1917. The model was damaged when the IWM was bombed during the Second World War and had deteriorated further. Haynes fully restored the model in superb detail for IWM but the model remained in store thereafter.

With the results of the multibeam, and knowing about the model, the idea came about to try and combine both into a single 3D visualization that juxtaposed the wreck with the original ship and could be made available to the public. The initial focus was on obtaining suitable access to the model from IWM, and taking initial advice on the feasibility of making a virtual model from John McCarthy, then at Wessex Archaeology in Edinburgh. Historic England's own Geospatial Imaging team came on-board to acquire data from the physical model and to develop the visualization. The timescale was limited because of the plan to publish and distribute a leaflet together with a media release in time for the centenary of Falmouth's loss on 19-20 August 2016. The IWM kindly provided access to the model at their store at Chatham Historic Dockyard. In view of the technical innovation and the short timescale, the initial aspiration was to obtain still images that juxtaposed the wreck and the ship model. The hope, however, was also to create a full visualization that the public could access and explore. As the opportunity and the aspiration were opportunistic and unavoidably short-term, no attempt could be made to set the exercise in a broader context in terms of methodologies or outcomes; the authors relied on the practical experience of their craft rather than a formal design process. 


\subsection{Data Acquisition and Processing of the Ship Model}

The Historic England Geospatial Imaging team visited Chatham Historic Dockyard on two days in mid-June 2016. The model was recorded using laser scanning and multiimage photogrammetry (Figs. 12.3 and 12.4).

The model was scanned using a Leica ScanStation P40 terrestrial scanner. The aim of the laser scanning was to provide control for the multi-image photogrammetry that was used to produce the finished model. The model was scanned from six positions with an average point spacing of $3 \mathrm{~mm}$. The scans were registered together to form a point cloud using resection to common targets. The scanner did not cope very well with the rigging so there was a lot of noise in that area. There were, however, plenty of points on the hull that could be used for control. The final model was generated from 891 photographs taken with a Sony ILCE-7RM2 camera. The photographs were taken so that they overlapped with at least two others and in most cases, many more. They were taken from as many different angles as possible to achieve complete coverage of the ship. Each image is $40 \mathrm{Mp}$ resulting in a $120 \mathrm{Mb}$ TIF file, so the photography resulted in $104 \mathrm{~GB}$ of imagery.

The photography was processed using the multi-image photogrammetry software RealityCapture by CapturingReality of Slovakia. This software allows the integration of laser scan data. Even using a high-end workstation with $128 \mathrm{Mb}$ RAM and specialist graphics card the processing took several days. Although the model was much less noisy than the laser scan data, it still required a lot of cleaning. In the end, the masts and associated rigging were removed from the final model.

The still images from the visualization were ready in time to include in the design of the fold-out leaflet. A preliminary animation was also prepared. It was decided, however, to concentrate on Sketchfab (2018) as a means of making the visualization available to the public, so that people could explore the visualization themselves rather than passively watching a fly-through. On Sketchfab, the visualization was accompanied by text with links to further information-including online versions of the fold-out

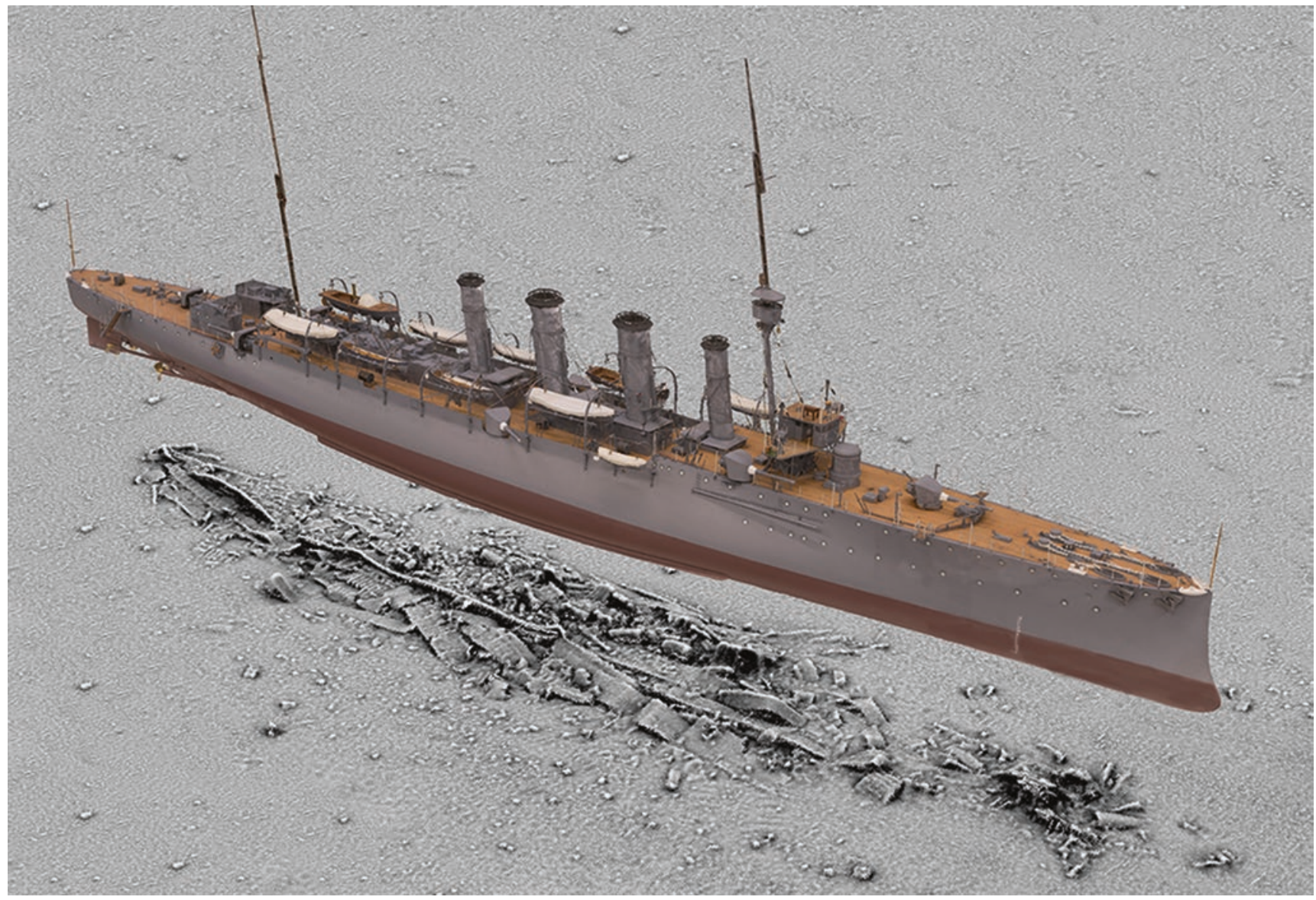

Fig. 12.4 Static image from the 3D visualisation of HMS Falmouth, as used in fold-out leaflet and press release. (Courtesy of Historic England. Maritime and Coastguard Agency (c) Crown copyright) 
leaflet and Statement of Significance-and numbered annotations were added to the visualization itself to highlight features of the ship and the wreck, and to tell the story of the seven torpedoes that resulted in Falmouth's loss.

\subsection{Publication of the 3D Visualization}

The 3D visualization of HMS Falmouth on Sketchfab was made public to coincide with a media release on the centenary of Falmouth's loss (Fig. 12.4). The fold-out leaflet with an image from the visualization was distributed to museums and Tourist Information Centres in time for the centenary. A link to the Sketchfab visualization was included in Historic England's own web page on HMS Falmouth (Historic England n.d.). The process of creating the visualization provided the hook for Historic England's press release: 'Jutland Wreck Brought to Life' (Historic England 2016). The still image from the visualization featured in the extensive national and regional press coverage of HMS Falmouth's centenary and the online versions of many newspapers embedded the Sketchfab visualization within their pages, adding to impact and connectivity (Table 12.1). The visualization also provided a striking image for posts on Twitter (hashtag \#HMSFalmouth); each event relating to the sinking of HMS Falmouth was 'live tweeted' on its to-the-minute centenary, adding to overall impact.

Creating a 3D visualization from such a detailed physical model was very demanding, especially within the short timescale available from data acquisition (15-16 June) to printed output as a fold-out leaflet in time for the centenary (19-20 August). As a result, there are limitations to the visualization. Much detail of the rigging had to be cut out and the ship is decidedly 'blocky' when zoomed in to the ship model. Nonetheless, the visualization contributed very significantly to the overall objective of raising awareness of HMS Falmouth, especially as a hook for the media. The visualization was a 'staff pick' on Sketchfab and as of May 2018 it has had over 21,400 views. The visualization, undoubtedly, will continue to serve as an intriguing conduit for people to find their way to more detailed information about HMS Falmouth.

\subsection{Development Potential of 3D Visualization for Further Research and Public Engagement}

The opportunistic development of a 3D visualization of HMS Falmouth achieved its immediate purpose, generating a great deal of media interest and views on Sketchfab to mark the centenary of Falmouth's loss. The visualization still holds great potential for further development, however, which may be relevant to how visualizations are considered more broadly amongst the tools available to archaeologists. In this regard, it is appropriate to consider the visualization on Sketchfab as a principal tool or output, rather than as popular outreach. A key benefit of visualizations on Sketchfab and other comparable platforms is their accessibility without recourse to the specialist software used in their preparation. They can be likened to the pdf of a journal article (especially as pdfs can now contain 3D content); easy to distribute and discuss, reflecting but not including the detailed data that underpins the conclusion. There is a need, of course, for methodological transparency, peer review and contestability. Such visualizations will undoubtedly improve in detail and capability as technology continues to progress. Even if current visualizations will seem rudimentary in only a few years, they can still be regarded as a reasoned foundation upon which further research, management options and public engagement can be based.

Arguably, the real foundation is the 3D survey dataacquired using multibeam, photogrammetry, laser scanning and so on-rather than the visualization. The presentation of $3 \mathrm{D}$ data in a way, however, that can be examined and explored directly by others-including those without specialist skills in the specific survey technologies-changes the context. Visualizations might be regarded as hypotheses reflecting the selectivity and choices made methodologically, but the result can still be tested and interrogated more than a $2 \mathrm{D}$ representation of the same data on a physical page. The accessibility of the platform adds to the openness of visualizations, which is important if discussions over

Table 12.1 Examples of press coverage of HMS Falmouth, August 2016

\begin{tabular}{l|l|l}
\hline The Guardian & $\begin{array}{l}\text { 19 August } \\
2016\end{array}$ & $\begin{array}{l}\text { https://www.theguardian.com/world/2016/aug/19/first-world-war-wreck-gets-virtual-restoration-off-coast- } \\
\text { of-yorkshire. Accessed May 2018 }\end{array}$ \\
\hline The Telegraph & $\begin{array}{l}\text { 19 August } \\
2016\end{array}$ & $\begin{array}{l}\text { http://www.telegraph.co.uk/science/2016/08/18/shipwreck-of-hms-falmouth-brought-back-to-life-on- } \\
\text { 100th-annivers/. Accessed May 2018 }\end{array}$ \\
\hline The Mirror & $\begin{array}{l}\text { 19 August } \\
\text { 2016 }\end{array}$ & $\begin{array}{l}\text { http://www.mirror.co.uk/news/uk-news/digital-wizardry-brings-sunken-world-8660979. Accessed May } \\
\text { 2018 }\end{array}$ \\
\hline $\begin{array}{l}\text { The Yorkshire } \\
\text { Post }\end{array}$ & $\begin{array}{l}\text { 19 August } \\
\text { http://www.yorkshirepost.co.uk/news/analysis/first-world-war-wreck-off-yorkshire-s-coast-brought-back- } \\
\text { to-life-1-8077498. Accessed May 2018 }\end{array}$ \\
\hline BBC News & $\begin{array}{l}20 \text { August } \\
\text { http://www.bbc.co.uk/news/uk-england-humber-37142617. Accessed May 2018 }\end{array}$ \\
\hline
\end{tabular}


future management or physical accessibility are being raised with for example the fishing community or local divers.

One of our aspirations was to incorporate other sources into the visualization, especially the large-scale plans, profiles and sections of Falmouth's sister-ship HMS Weymouth which are held by the National Maritime Museum. The capacity of visualizations to enable the public to access wrecks which are remote to most people is often commented upon (Kenderdine 1998, 17; Reunanen et al. 2015, 24.3). The same is also true of resources such as documents, drawings, photographs and models that are not intrinsically remote but which are not easily accessible because they are spread around various institutions, in store and/or require special handling. Enabling people to explore such sources virtually-juxtaposed with the ship as a 3D entity and with the remains on the seabed-is a prize worth pursuing.

As well as physical remoteness, the HMS Falmouth visualization might also be considered to counteract a form of conceptual remoteness also. Shipwreck data are not always easy to 'read.' As Adams notes, 'even to experienced eyes the relationship of many wrecks to the complete entity they once were is often far from clear' (Adams 2013, 94). One of the benefits of multibeam is that images are more readily understood by lay people than other forms of remote sensing, at least in the case of relatively intact wrecks, but HMS Falmouth is perhaps more typical of the many wrecks that are already quite degraded. Using 3D visualizations to juxtapose wrecks with the ships they once were, as we have done in this instance, is therefore a means of making shipwrecks less remote conceptually as well as physically. Even this simple juxtaposition suggests that the remains of HMS Falmouth are more complete and coherent than the history of clearance and salvage might suggest-especially in the buried portion of the lower hull. The impression is at odds with the earlier perception of the wreck as a scrapyard and a good rummage. Hence, conceptual access is not just about reaching audiences: making an association with the ship could help elevate the physical material from random wreckage to meaningful heritage, nudging behaviours towards maritime archaeology both on site and in wider society.

The visualization has also helped in identifying the original position of photographs of crew taken aboard Falmouth (Figs. 12.5 and 12.6), which it might be possible to include in the visualization in future. This has two important aspects. First, it helps in placing people back aboard the ship, to present it as a human, lived-in space, even aboard a warship that was in the thick of the action at times. Although it is possible to place crew photographs based on ship drawings or models, the ability to obtain the same viewpoint as the camera and recreate the same immediate landscape of the people in the historic image provides-literally - a new perspective on the vessel (Fig. 12.5). This is especially valuable insofar as the human dimension of ships in use tends to be obscured by

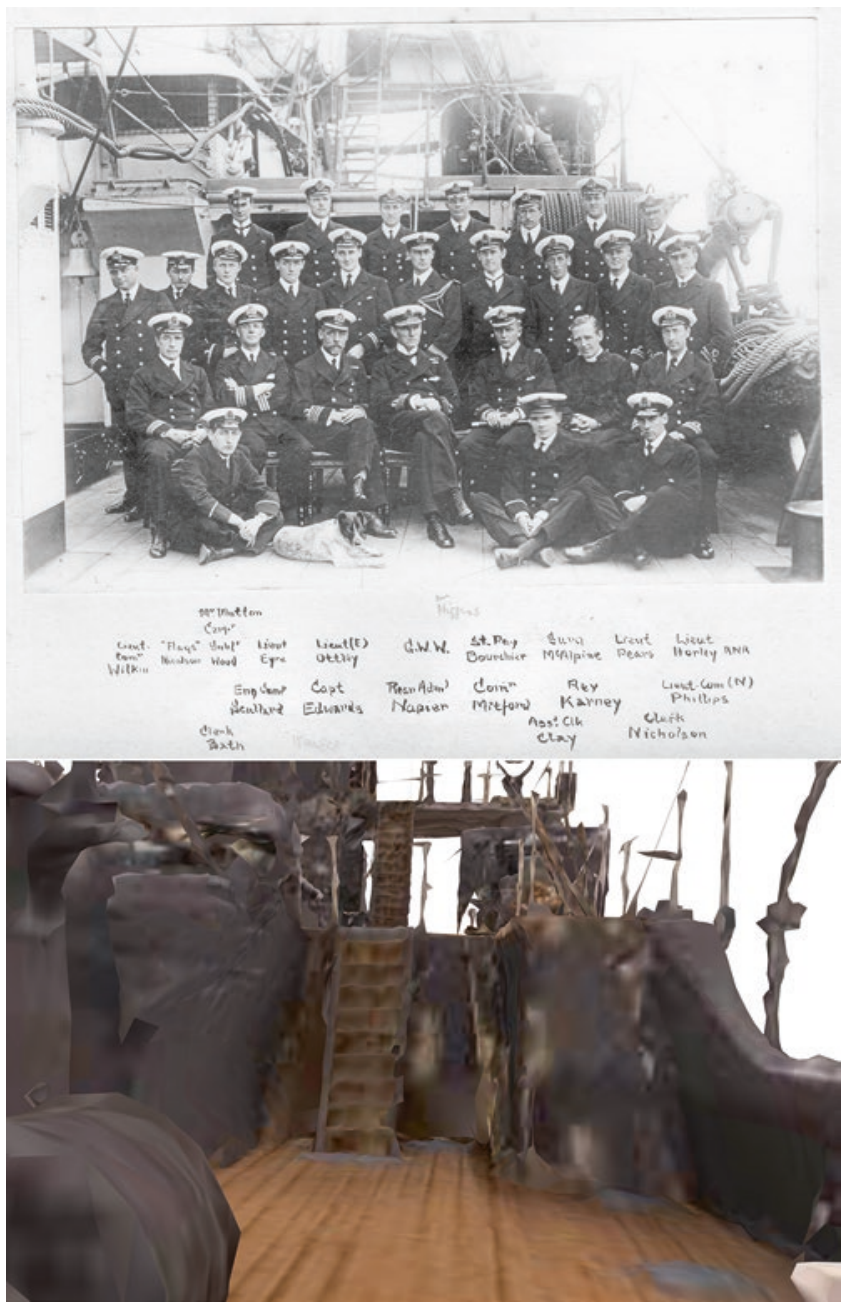

Fig. 12.5 Top: Photograph of HMS Falmouth's officers, probably taken in summer 1916 around the time of the Battle of Jutland. (Courtesy John McDonald). Bottom: The 3D visualisation of the area corresponding to the officers' photograph. (Maritime and Coastguard Agency (C Crown copyright)

a focus on their design and construction, or on the circumstances of loss. As Adams notes, visualization can help ensure that 'a ship as a thing cannot be separated from the people who conceived, designed, built, used and either lost or disposed of it' (Adams 2013, 94). Thinking especially about models such as that of HMS Falmouth, which exist in museum collections and stores in profusion, the comments of Cooper et al. $(2018,17)$ are apposite:

\footnotetext{
An abiding challenge for the presentation of watercraft in a dry and static museum gallery is the fact that boats and ships are, in their intended applications, dynamic structures in ever changing aquatic environment. Digital modelling ... enables museums to overcome the stasis of the museum object ... and engage visitors with the lived experience of vessels ...
}

In this respect, the attempt to place crew photographs aboard Falmouth using the visualization resonated strongly with a line from the diary of a young gunnery officer, 


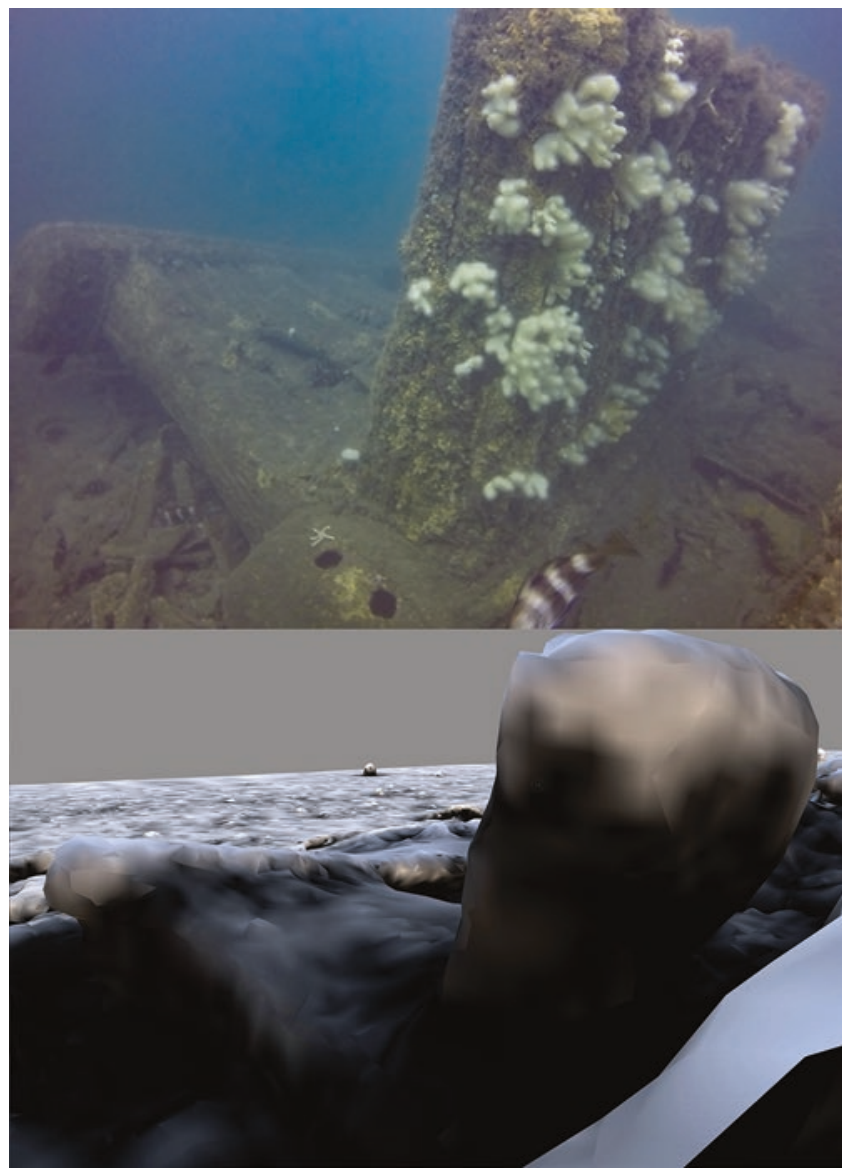

Fig. 12.6 Top: Photograph of one of Falmouth's Y-shaped Yarrow boilers, taken by local diver Mike Radley. (Mike Radley). Bottom: Yarrow Boiler Screenshot. (Maritime and Coastguard Agency (c) Crown copyright)

Arnold Pears, aboard Falmouth at Jutland and at the time of its loss (LIDDLE/WW1/RNMN/235):

I have no heart to write ... the loss of that ship, the symbol to me of my home, my work, my play, my life, my companion in danger, hits me too hard ...

The second important aspect of crew photographs is that the visualization has formed part of a project that has become a focus for members of the public to contribute their own stories, associations and sources to HMS Falmouth. This was not a key objective but is a somewhat unintentional (though very welcome) consequence of social media. Photographs and documents relating to the crew have some to light from privately held, personal archives that have been handed down or acquired in conjunction with, for example, medal collecting as a hobby. The personal connections to Falmouth's crew add considerably to the significance of the vessel as well as being a further source of primary evidence. It cannot be claimed that visualization of HMS Falmouth was an exercise in participation and co-production, as encouraged by Jones et al. (2018). HMS Falmouth does, however, at least point in the direction that such a project might take in the marine sphere. Visualization could prompt and provide a focus for the public in researching their own connections to ships like HMS Falmouth and major themes such as the First World War at sea. This would help to unlock the huge potential of historic material held privately in families and communities, enabling the public to contribute their own knowledge and associations and thereby shape their own maritime histories.

Further opportunities for community-based co-production are provided by the scope to combine the visualization with still photographs and videos of the wreck taken by divers (Fig. 12.6), enabling components of the wreck to be identified and observations to be made on survival and condition. Although the current visualization does not incorporate the ship drawings and diver photographs, it has been used alongside such sources to better understand what survives of the machinery spaces of HMS Falmouth, for example. The visualization could also be used as a focus for future fieldwork by volunteers, perhaps adding detail to the current visualization with localized 3D models derived from underwater photography. Together with the supporting fold-out booklet, the visualization can already help recreational divers to better understand the wreck and the relationship of its features to the original ship. There is potential also for the visualization to provide the basis for a 'virtual dive trail' that will enable the non-diving public to visit the wreck.

Remarkably, HMS Falmouth's Armed Steam Cutter-the principal ship's boat, which provided an important element of the ship's capability as a light cruiser-has survived to the present day, despite being abandoned at the time of loss. The cutter was recovered as salvage by a fishing boat (ADM 116/1508) and, after a career of its own, has been acquired by Portsmouth Naval Base Historic Trust. The Trust intends to restore the cutter to steam as part of its Memorial Fleet of small boats. The cutter is prominent on the builder's model and has been highlighted on Sketchfab, underlining the tremendous range of hitherto disparate historical and archaeological sources that are being re-connected and integrated by the visualization.

\subsection{Conclusions}

3D visualization of HMS Falmouth has contributed substantively to the project's objective of raising awareness of the significance of a known but undervalued wreck, making the story of the ship accessible to a much wider audience. 
The project has successfully combined specialist survey data from a degraded wreck with a builder's model that has been hidden from the public for at least 70 years. In a sense, this was an entirely satisfactory end point, but it should also be apparent that $3 \mathrm{D}$ visualizations such as that of HMS Falmouth are not only a product to be measured in terms of the number of views they receive. Rather, the visualization of HMS Falmouth is part of a process that will extend well into the future, alongside the wreck and the many other archive sources—physical and documentary; held publicly and privately - that relate to Falmouth's story. The visualization has a special place because of its capacity to help integrate so much disparate and often inaccessible material: a seed dangling in 3D space around which the overlooked history of HMS Falmouth can, in time, crystallize. Importantly, the visualization exists in a public space and engagement with communities, whether locally on the Yorkshire coast or globally across the web, will continue to add many facets to Falmouth's story. Looking beyond this particular wreck, it is hoped that the project points the way to far greater use of 3D visualization to bring to life underwater cultural heritage, representing and reconnecting the full range of evidence upon which we draw. The capacity to juxtapose survey data and ship models is especially worth pursuing, to mobilize plentiful but underused resources to shine a light on the UK's mid-nineteenth- to mid-twentiethcentury maritime history. Finally, the 3D juxtaposition of wreck and ship reminds us to see shipwrecks as inhabited places; to focus on people as well as their technology.

Acknowledgements This chapter has been prepared by Antony Firth of Fjordr Limited with contributions from Jon Bedford and David Andrews of Historic England, who carried out the photogrammetry and laser scanning of the ship model and the combined 3D visualization. The HMS Falmouth project as a whole was funded by Historic England; our thanks go to Wayne Cocroft and Gareth Watkins. Access to the builder's model of HMS Falmouth was provided by the Imperial War Museums courtesy of Maria Rollo. John Haynes, model maker and restorer, kindly provided information and photographs that helped in identifying the builder's model. Thanks are also due to John McCarthy for initial advice on the feasibility of scanning the builder's model. The multibeam survey was commissioned, with the support of Historic England, by the Maritime and Coastguard Agency (MCA) from their survey contractor MMT; Robert Kinnear and Paula English of MCA and Martin Godfrey at MMT all have our gratitude. Information on the significance of HMS Falmouth's cutter, and access to the boat itself, has been provided by Portsmouth Historic Naval Base Trust courtesy of Peter Goodship and Diggory Rose. The background research on HMS Falmouth has drawn on archives held by a wide range of institutions and private individuals, whose kind assistance is gratefully acknowledged. Attributions for images are noted in the figure captions. We are grateful also to the editors and an anonymous reviewer for comments which strengthened the paper in review.

\section{References}

Adams JR (2013) Experiencing shipwrecks and the primacy of vision. In: Adams JR, Ronnby J (eds) Interpreting shipwrecks: maritime archaeological approaches. The Highfield Press, Southampton, pp 85-96

ADM (116/1508) HMS Falmouth salvage of guns etc. The National Archives

Cooper JP, Wetherelt A, Zazzaro C, Eyre M (2018) From Boatyard to museum: 3D laser scanning and digital modelling of the Qatar Museums watercraft collection, Doha, Qatar. Int J Naut Archaeol 47(2):419-442. https://doi.org/10.1111/ 1095-9270.12298

Divernet (n.d.) 100 Best UK wreck dives: the HMS Falmouth-78. http://www.divernet.com/100-best-uk-wreck-dives/p301908-thehms-falmouth-78.html. Accessed May 2018

Firth A (2011) Marine geophysics: integrated approaches to sensing the seabed. In: Cowley D (ed) Remote sensing for archaeological heritage management, EAC Occasional Paper No, 5. Europae Archaeologia Consilium, Brussels, pp 129-140

Firth A (2016a) Wreck of HMS Falmouth, off Bridlington: statement of significance with supporting narrative. Unpublished document for Historic England. https://content.historicengland.org.uk/content/ docs/wreck-hms-falmouth-statement-of-significance.pdf. Accessed Sept 2017

Firth A (2016b) The wreck of HMS Falmouth: First World War 'Town Class' light cruiser and Jutland veteran sunk by U-boats off the Yorkshire coast on 19-20 August 1916. Leaflet prepared on behalf of Historic England. http://content.historicengland.org.uk/content/docs/hms-falmouth-broadsheet.pdf. Accessed May 2018

Firth A (2016c) Jutland: an archaeological perspective. In: Sheldon M (ed) 36 hours: Jutland 1916 - the battle that won the war. National Museum of the Royal Navy, Portsmouth

Firth A, Rowe P (2016) The national importance of cargo vessels: Tees pilot. Unpublished report for Historic England. Project Number HE 7051, Fjordr Ref: 16261. Fjordr Limited, Tisbury. https://historicengland.org.uk/images-books/publications/national-importancecargo-vessels-teespilot/national-importance-of-cargo-vesselstees-pilot-report/. Accessed Dec 2018

Historic England (2016) Secrets of the deep-Jutland Wreck brought to life. https://historicengland.org.uk/whats-new/news/jutland-wreckbrought-to-life. Accessed May 2018

Historic England (n.d.) HMS Falmouth: a veteran of the Battle of Jutland. https://historicengland.org.uk/whats-new/first-world-warhome-front/what-we-already-know/sea/hms-falmouth/. Accessed May 2018

Jones S, Jeffrey S, Maxwell M, Hale A, Jones C (2018) 3D heritage visualisation and the negotiation of authenticity: the ACCORD project. Int J Herit Stud 24(4). https://doi.org/10.1080/13527258.2017. 1378905

Kenderdine S (1998) Sailing on the silicon sea: the design of a virtual maritime museum. Arch Mus Inform 12(1):17-38

LIDDLE/WW1/RNMN/235 (PEARS, S ARNOLD) Leeds University Library, Liddle Collection

Lyon D (1977) The first town class 1908-31, Parts I-III. Warship 1977:1-3, 48-58, 54-61, 46-51

Menna F, Nocerino E, Scamardella A (2011) Reverse engineering and $3 \mathrm{D}$ modelling for digital documentation of maritime heritage. Int Arch Photogramm, Remote Sens Spat Inf 
Sci XXXVIII(5/W16):245-252.

isprsarchives-XXXVIII-5-W16-245-2011

Newbolt H (1928) Naval operations: history of the Great War based on official documents, vol IV. Naval \& Military Press, Uckfield, Reprint, 2003
Reunanen M, Díaz L, Horttana T (2015) A holistic user-centered approach to immersive digital cultural heritage installations: case Vrouw Maria. J Comput Cult Herit 7(4):24.1-24.16. https://doi. org/10.1145/2637485

Sketchfab (2018) https://sketchfab.com. Accessed 23 July 2018

Open Access This chapter is licensed under the terms of the Creative Commons Attribution 4.0 International License (http://creativecommons. org/licenses/by/4.0/), which permits use, sharing, adaptation, distribution and reproduction in any medium or format, as long as you give appropriate credit to the original author(s) and the source, provide a link to the Creative Commons licence and indicate if changes were made.

The images or other third party material in this chapter are included in the chapter's Creative Commons licence, unless indicated otherwise in a credit line to the material. If material is not included in the chapter's Creative Commons licence and your intended use is not permitted by statutory regulation or exceeds the permitted use, you will need to obtain permission directly from the copyright holder. 